\title{
The Copyright Risk of MOOC and the Countermeasures of University Libraries
}

\author{
Libin Zhang, Nankai University Library, Tianjin, China \\ Guo Wang, School of Law, Tianjin University of Commerce, Tianjin, China \\ Yihang Li, Shenzhen Graduate School, Harbin Institute of Technology, Beijing, China \\ Qun Hao, Fudan University Library, Shanghai, China \\ Huiming Chai, Tianjin Music College Library, Tianjin, China \\ Jiamin Wu, School of Law, Nankai University, Tianjin, China
}

\begin{abstract}
With the rapid development of MOOCs, copyright risks related to the MOOC cannot be ignored. MOOCs rely on multimedia technology, and the fragmented characteristics of its sources and the profitability of the MOOC involve more complicated legal relationships. It has been proven that an effective way of dealing with copyright risk is through the participation of university libraries in MOOCs. The practical significance of this paper lies in how to exert a library's professional advantages and how to participate in MOOC production in order to solve the copyright risk of MOOC. Furthermore, the rapid development of MOOCs provides the realistic basis for speeding up the legislative process for the adjustment of copyright regulations. Therefore, it is necessary to perfect the copyright legislation related to MOOCs: let no masterworks get into the public domain but allow the orphan works to be used directly on the premise of paying an escrow fee.
\end{abstract}

\section{KEYWORDS}

Copyright Clearance, Library, MOOC, Platform of MOOC

\section{INTRODUCTION}

With the rapid development of MOOC (Reil, 2012), the copyright risks related to MOOC cannot be neglected. MOOC rely on multimedia technology, the fragmented characteristics of its sources involves a more complicated legal relationship (Fang, 2014). The profitability of the MOOC platform itself makes the MOOC more prone to copyright infringement compared to traditional works. In response to copyright risks, the inclusion of librarians in the MOOC project team is considered by many organizations as the most feasible way to prevent copyright infringement. With Coursera, in universities such as the University of Toronto and Brown University, librarians play a leading role in facilitating the transition of academic personnel to the MOOC teaching environment. Similar trends are shown in the EDX network (Luo, 2014). Foreign university libraries provide multi-directional information services for MOOC production and development by providing effective literature

This article, published as an Open Access article on April 23, 2021 in the gold Open Access journal, International Journal of Library and Information Services (converted to gold Open Access January 1, 2021), is distributed under the terms of the Creative Commons Attribution License (http://creativecommons.org/licenses/by/4.0/) which permits unrestricted use, distribution, and production in any medium, provided the author of the original work and original publication source are properly credited. 
information, publishing copyright guidelines, clearing up copyright misconceptions, developing copyright information literacy education and taking part in curriculum production and management.

\section{Particularity and Complexity of MOOC Cause Copyright Risks}

MOOC relies on multimedia technology to function. Multimedia is generally considered to be text, numbers, graphics, images, audio, video and other forms of information integrated in media as well as the use of media to achieve intelligent operation of the environment (Qin, 1999). Depending on the difficulty involved with making the MOOC videos, they can be divided into the following categories, as shown in Table 1.

\section{Fragmentation Leads to the Difficulty of Accurately Identifying the Right State of Information Resources}

Firstly, whether the fragmented resources in a MOOC video are protected by copyright needs to be identified. If the copyright protection period has expired, it does not meet the copyright element. The knowledge and facts in the public domain of information resources naturally do not pose an infringement risk and it may be used arbitrarily. However, the principles of automatic copyright

Table 1. Typical types of video production methods of different grades (Li \& Liu, 2016)

\begin{tabular}{|c|c|c|}
\hline Difficulty & Type & Explanation \\
\hline \multirow{3}{*}{ Simple } & $\begin{array}{l}\text { Slide Show } \\
\text { Synchronizing } \\
\text { Recordings }\end{array}$ & $\begin{array}{l}\text { Uses the recording software to record the slides on the screen and it is usually } \\
\text { accompanied by a teacher's explanation. The pen can be used to sketch and } \\
\text { standardize the content on the screen without a teacher's comment but with } \\
\text { background music added to it. }\end{array}$ \\
\hline & $\begin{array}{l}\text { Screen Operation } \\
\text { Video Recording }\end{array}$ & $\begin{array}{l}\text { Records the operation, steps and processes of the teacher on the compute, often used } \\
\text { in computer programming courses software teaching classes. }\end{array}$ \\
\hline & $\begin{array}{l}\text { Khan Style } \\
\text { Explanation } \\
\text { Video }\end{array}$ & $\begin{array}{l}\text { To create a one-to-one explanation atmosphere, the tutorial does not use PPT, but } \\
\text { uses a Tablet PC to do handwriting or films the process of paining on paper without } \\
\text { a Tablet PC. }\end{array}$ \\
\hline \multirow{3}{*}{ Medium } & Lecture Clips & $\begin{array}{l}\text { This records all interactions at the teaching hall. It records the teacher in close } \\
\text { range, the teacher's natural performance, multiple seats and the student present and } \\
\text { a complete interaction with students. It is very easy to record but the length of the } \\
\text { video is long and there is a need to read/watch with perseverance. }\end{array}$ \\
\hline & Special Scenes & $\begin{array}{l}\text { This involves filming teachers in special scenes such as offices, laboratories and } \\
\text { other teaching videos. This kind of video format can create an immersive feeling } \\
\text { for students. In shooting a special scene, it is important to consider the weather, } \\
\text { lighting, noise as well as other factors. }\end{array}$ \\
\hline & $\begin{array}{l}\text { Mix Teacher } \\
\text { Scenes and PPT }\end{array}$ & $\begin{array}{l}\text { Adds an independent recorded teacher to the presentation. The image of the teacher } \\
\text { in the picture can be very small and also can be separated. A common form of this is } \\
\text { when a teacher is seen explaining and after a PPT turns up. }\end{array}$ \\
\hline \multirow{3}{*}{ Complex } & Animation Demo & $\begin{array}{l}\text { The teaching content is conveyed through animation. Teachers and real world } \\
\text { entities do not appear. It needs a professional design and it involves a high cost of } \\
\text { production. }\end{array}$ \\
\hline & Virtual Studio & $\begin{array}{l}\text { Teachers stand in front of a green screen whiles facing the camera in the studio } \\
\text { during recording. The camera records courses and post-production of scene elements } \\
\text { and teaching content are added together to become a complete video. Special } \\
\text { lighting, large screen and a green curtain are needed in this type. }\end{array}$ \\
\hline & $\begin{array}{l}\text { Film-level } \\
\text { production }\end{array}$ & $\begin{array}{l}\text { According to the standard film level of shooting, production of the video needs } \\
\text { multiple frames. Shooting must have a rich content such as aerial photography, } \\
\text { multi-angle shooting (more than } 3 \text { lenses) and many others. It must also use a } \\
\text { complex post-production processing technique to process videos }\end{array}$ \\
\hline
\end{tabular}


protection include voluntary registration, and the state of information resources as public or proprietary is not self-evident, especially in the electronic form of public dissemination as compared to paperbased media. The copyright information of electronic media is often more concise, or even completely missing. In such cases, it is difficult to accurately identify the right state of information resources (Chen, 2015).

Secondly, knowing that the information resources used are within the scope of copyright protection, that is, MOOC developers face the dilemma of how to obtain authorization. It is difficult to ascertain the holder of the copyright since the right attribution of the fragmented work is also fragmented, so it is not easy to contact holders and authorize consultations with the main body of rights. The copyright content in our country uses the "personal property two-yuan system structure" through which the rights are not transferable or inherited. Once the work is transferred or inherited, it means that both the original author and the right holder are authorized to be contacted. The situation is more complicated if the subject of the right is difficult to determine, or cannot be contacted, that is, orphan works. The existence of "orphan works" in copyright resources used by MOOC is a gap that cannot be bridged in video production. A survey conducted by the European Commission from November to December 2009 shows that in Europe, 3 million copyrighted works are orphans (13 of the total); $20 \%$ of orphan audiovisual works are archived by the European Film Archive. The proportion of orphans in photographic work held by British museums is as high as 90\% (Vuopala, 2010). In addition, current copyright law does not include the use of orphan works in statutory licensing or use the category of reasonable use in the MOOC course video production. The use of orphan works still carries the risk of infringement.

\section{Diversity Leads to the Difficulty in Accurately Defining the Legal Relationship of Copyright Resources}

The legal relationship involved in MOOC video consists of the following two aspects. First, there is the legal relationship formed by the copyrighted resources used in MOOC videos. MOOC video contains a variety of different types of works. The different creative styles have different legal natures such as personal works, job titles, cooperation works, and commissioned works. The rules of attribution of rights of different types of works are not the same, and even different types of work can overlap and conflict. In the case of a legal person's work and special duties, Article 11 of the Copyright Act requirements states that where a work is created according to the intention and under the supervision and responsibility of a legal entity or another organization, such legal entity or organization shall be the author of the work. Article 16 also stipulates that in the case of drawings, engineering designs, product designs, maps, computer software and other service works which are created mainly with the materials and technical resources of the legal entity or organization and under its responsibility, the author of a service work shall enjoy the rights of authorship, while the legal entity or organization shall enjoy other rights included in the copyright and may reward the author. Therefore, in terms of these two articles, some works may conform to the elements of the legal person's works and special duty works, but there is no consensus between the theoretical and practical circles on what type of copyright ownership they fall under. The uncertainty of the legal nature also constitutes one of the main sources of MOOC video copyright risk.

Second, there is the newly formed legal relationship in the process of MOOC production. MOOC involves a number of stakeholders including teachers, students, universities, platforms, publishers, etc. All stakeholders are intertwined as shown in Figure 1. MOOC copyright is very complicated because of the different motives and demands of various stakeholders. Because the motives and needs are complex, the solution of the MOOC copyright issue needs to be settled through public discussion and approval between the university, the teacher and the platform provider (Wang, 2014).

On one hand, the course video in a MOOC is usually made by the teacher and it is disseminated by the university and platform, but more depends on the platform. The three may form a relationship of entrustment, cooperation and duty. How to determine the copyright attribution of MOOC video 


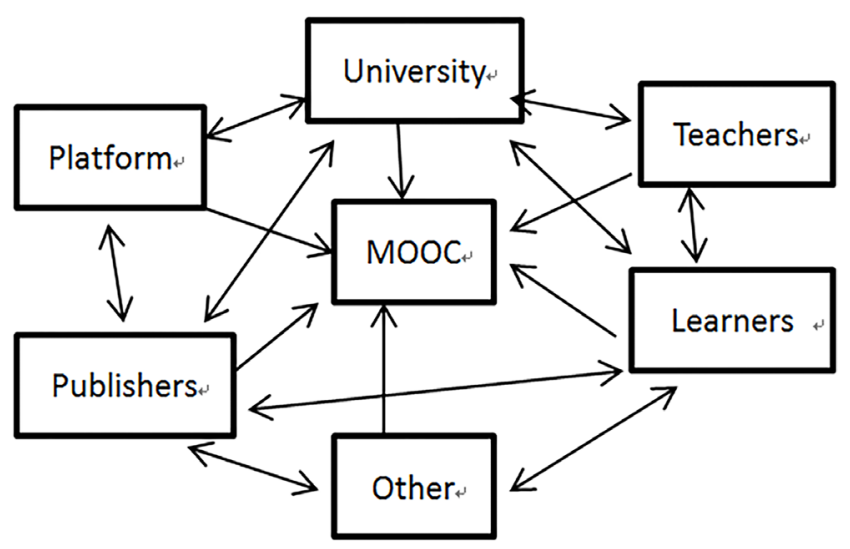

becomes a focus controversy. In addition, MOOC video is supported by multimedia technology. There is no consensus on what kind of works the multimedia works belong to in the copyright law. One view is that, compared with traditional works, the biggest feature of multimedia works is their interactivity, and so they should be categorized by that feature. Another view is that multimedia works can be classified with traditional works because only their form of expression are different, such as compilation works, the computer software, the database, the movie work and so on. With the deepening of research, it has been found that multimedia works are rich and colorful, and it is difficult to use uniform labels. It has even been argued that the idea of multimedia as a special type of media has vanished (Cui, 2016). How to determine the copyright ownership of MOOC video is a very difficult problem.

On the other hand, MOOC has a better course experience than the first generation of online open classes. It is more like moving the traditional classroom online. It is no longer "plug-in" networkassisted teaching but a "built-in" approach to teaching from "teaching-led learning" to "study the promotion of learning" (Qin, 2014). Therefore, MOOC teaching has the generative characteristics of a resource. Students can use unstructured communication channels with teachers, experts or other students to communicate and constantly generate new answers, evaluations, reports, advisory opinions and other information. According to the principle of copyright law, students should enjoy the copyright of MOOC on the part of their creation (Fang, 2016). At present, the copyright ownership of generative resources is not clear. Most MOOC education platforms have chosen to apply the knowledge-sharing license agreement, which requires the learner to recognize the right to free use of the MOOC education platform under the agreement when registering. The following steps will be difficult if the user does not agree to the terms of service provided by the MOOC education platform at the time of registration. Therefore, in order to gain access to online learning, the majority of learners will choose abide by the service agreement of the MOOC education platform. It is obviously unfair that the MOOC educational platform utilizes its own strong position to leverage the terms and conditions of the copyright contract for their own advantage (Zhang \& Zheng, 2016). Consequently, it is not reasonable to compulsorily obtain the copyright of student's homework. It could be a potential source of future copyright crises.

\section{Difficulty in Applying Fair Use of New Features of MOOC}

MOOC education uses modern network technology to realize "online" teaching which has different features from traditional education, and these new features limit the application of the "fair use" rule.

First, the open features of MOOC education conflict with the limited scope of fair use. In accordance with the provisions of the Technology, Education and Copyright Harmonization Act 
(Teach Act), promulgated by the United States in 2002, teaching content can only be transferred to students enrolled in the course. Janeden Hollander, Vice President of the University of Dickon, Australia said "the teaching content is geared towards students with university backgrounds, which means that the content of the course can be regulated and when it is passed on to all MOOC students, the problem follows" (Intellectual Property Protection in China, 2013). These problems exist in China too. The provisions of the copyright law for fair use are enumerated. One of the provisions relevant to MOOC education is on the translation or reproduction in a small quantity of copies of a published work for use by teachers or scientific researchers in classroom teaching or scientific research provided the translation or reproduction shall not be published or distributed. It should read: the right to disseminate information should emphasize the reasonable use of relevant teaching and scientific research is clearly limited to the scope of "minority teaching or scientific research personnel" and "a few published works." China's copyright law and the regulations on the protection of the right to disseminate information should emphasize traditional classroom teaching. The number of student in a traditional classroom is small, and the students belong to the "pure consumer group" which does not have an income source. The teacher uses teaching materials in the classroom that are reproduced by way of printing, which easily controls the damage of the latent value of the work (Zou \& Chen, 2015). MOOC education has just broken through the limit of a geographical area and the number of students, so it becomes difficult to control damage to the latent value of the work caused by the teachers using the teaching materials. Therefore, if fair use rules are applied to MOOC, it unreasonably harms the copyright owner's interests. This understanding should be consistent with the objective of a reasonable system. The purpose of fair use is to ensure the public's right to know social information $(W u, 1996)$ and to ensure that the public can approach copyrighted works; that is, they can obtain ideas, materials, knowledge and information from the works (Feng, 2009). The fair use rule only protects the chance to "access" to copyright material, and further use after access does not necessarily allow the application of fair use rule. The fair use rule itself is a limitation of copyright and also an exception in tort law. Considering the systematic characteristic of copyright law, tort is the norm and the exception to tort is accidental. Therefore, the fair use rule should be explained and applied strictly.

On the other hand, the profit-making fees of MOOC education conflicts with the non-profitmaking request of the fair use rule. In the teaching management activities of MOOC education, the educational institution is no longer a single main body; the MOOC platform is as well. The MOOC platform is the technical platform of MOOC education. It is not only the learning place of students but also handles the administrative duties of some traditional educational institutions (Zou \& Chen, 2015). It is reasonable to charge a certain fee to maintain the operation of the MOOC platform. These fees are usually based on the corresponding additional services like students through the course platform can be free to complete each course of study but if they want to obtain course certification or credits, they need to pay the fee. The original public-spirited open learning platform has gradually moved towards a commercial platform for profit-making, which is a key obstacle for the fair use of MOOC.

Although the amendment draft of the copyright law adds the revealed clauses to reasonable use, it is still generally limited to personal use or for the purpose of public service. Although, according to the existing law, MOOC is beneficial to public interest to a certain extent, the commercial purpose cannot be excluded in the determination of reasonable use. The American standard has little significance to Chinese judicial practice. This is because the legislative mode adopted by the two countries is completely different, and the Chinese law excludes profitmaking investigation. First, the corresponding system environment is lacking in China. From the legislation point of view, although the United States Copyright Law Article 107 of fair use outlines the specific enumeration, it also determines the reasonable use based on four factors namely: (1) the purpose and characteristics of use, including whether the use is commercial in nature or for the purpose of non-profit teaching; (2) the nature of the copyright works; (3) the quality and quantity of the part used and the relation of the copyright works as a whole, and (4) 
the effect of the use on the potential market or value of the copyrighted work. This flexibility stipulates that "in some cases, when a tort is found to stifle the creativity of the law intended to promote, the provision will allow and require the court to avoid strict application of copyright law" (Campbell v. Acuff-Rose Music, Inc., 1994). This allows the judge to continue to develop the applicable scope of fair use through jurisprudence based on case determination. Second, the United States jurisprudence has recognized that commercial purposes have no real effect on the reasonableness of their use, so the court considers almost all the use of an interpretative nature referred to in the preamble to Article 107, including press coverage, commentary, criticism, teaching, research and investigation. All people in China are for the purpose of profit, and there is no one who writes for money, except for a fool (Wang, 2013). However, Chinese law is not clear about the reasonable use of judgment standard in practice, and a judge's discretion is very minimal. Even if they can decide freely, judges need to follow the reasonable use of common character namely "non-profit-making." Therefore, the commercial charges of the MOOC platform have deprived them of the basis for invoking reasonable use.

\section{THE RATIONALITY AND FEASIBILITY OF THE UNIVERSITY LIBRARY'S PARTICIPATION IN MOOC PRODUCTION}

At present, the university library has developed into an information space comprising both the physical form and the digital form, including the learning room, the laboratory and the virtual reference consultation, which make the library the perfect complement to the MOOC (Librarians, 2013).

\section{The Professional Advantage of the Library in MOOC Production}

Compared with individuals, libraries have a significant advantage in MOOC Copyright cleanup. The first is the advantages of the library compared to other institutions or departments. First of all, the library has a wealth of collection resources, and these resources are usually based on the classification of the subject set to retrieve. More importantly, the copyright status of the collection of resources is clear, whether subject is under copyright protection, who holds the copyright, the mode of licensing geometry and so on has been identified. With the exploitation of resources of the MOOC, if the resources themselves are in the public domain or within the scope of the library's authorization, there is no doubt that these resources can be used directly without authorization consultation. The abundant collection resources in the library can also help provide alternative literature if other unauthorized information resources are involved, so as to meet the information needs of course development. In the process of construction and maintenance, the library will form a good, stable cooperative relationship with other organizations such as publishers, database makers, etc. Once the MOOC development process is required to negotiate with these institutions for the authorization of information resources, the overall participation of the library in the negotiations will be more easily accepted, as a result of status, strength and reciprocity, than the individual negotiations.

The second advantage of the library is librarians and their expertise as compared to other staff. The librarian's copyright literacy is usually high. A large part of their daily work is engaging in copyright-related activities such as the collection of all books, periodicals classification, cataloging and standardization work. According to the school's teaching and scientific research needs, librarians subscribe to books, periodicals, and newspapers. According to the document resource development policy, they do so by interviews, election, discarding of old work, and so on. Librarians are more aware of the copyright status of all kinds of documents and the experience of librarians is richer when it comes to how to obtain all kinds of documents and their authorization. Therefore, compared to general teaching and research personnel, librarians engaged in MOOC copyright clean-up work is more advantageous. 


\section{THE WAYS LIBRARIES PARTICIPATE IN MOOC}

Practice has proved that there are various ways university libraries participate in MOOC production, but it mainly manifests in the following several aspects.

\section{Provision of Physical Facilities and Information Resources}

On the one hand, the transformation and innovation of University Libraries in recent days has developed them into an information-sharing space (IC) in a physical and virtual form, equipped with a training room, audio-visual room, electronic reading room, multimedia workstation and virtual reference service, which make the libraries a MOOCs supplement (Qin, 2014). Therefore, the library can provide physical facilities for MOOC. It can be used as a place for curriculum production, providing the necessary multi-media equipment, and as information center with abundant resources and good learning space. The library is also the best place for students to take part in the course study.

On the other hand, the library has a wealth of information resources, including not only paper resources, but also various types of digital resources such as digital periodicals, images, data, and videos so on. The library may use its own collection of resources, identified and collected open access, public domain or other freely available resources, as a course reading material or supplementary textbooks to help the teaching staff.

\section{Participation in the Production and Management of Courses}

MOOC relies on multimedia technology to maintain the normal operation of MOOC, the technical requirements for video and video editing. This technical support is just the technical advantage of the Library 2.0. The library can provide this support through the multimedia workstation in the IC or through an embedded subject librarian. The Stanford University Library for example, provides support for MOOC-related videos through the Academic Computing team which is part of its service work (Calter, 2013).

With more and more MOOC's, how to manage these digital courses is also a matter of library concern since the library's job is to classify and catalogue information resources, provide effective retrieval services and properly keep resources. It is naturally most appropriate for the library to serve as the MOOC administrator.

\section{As a Copyright Consultant}

MOOC can lead to complex copyright issues. As a copyright manager on campus, many foreign university libraries help MOOC teachers carry out the work of copyright cleaning, which is the most active way for the library to participate in MOOC (Qin, 2014). The library serves as a copyright consultant in following two main areas.

The first is the development of a copyright guide. The purpose is to help course producers understand the use of copyrighted material in the MOOC development process such as identifying different types of works, indicating what circumstances can enable reasonable use, explaining how to obtain the public domain or open access resources, etc.

Second, copyright clearance means that in order to ensure the smooth use of information resources by relevant parties, the library must deal with information agencies through a series of legal means and deal with independent copyright resources in order to eliminate copyright disputes that may arise (Peng, 2015). In addition to verifying the copyright status of the course content, the most critical duty of the library is to assist the producer in obtaining authorization for third-party content, and to collect open information resources as a substitute for copyrighted course materials. Again, the library can work with the legal office to assess the right to use third party material and determine whether it constitutes a reasonable use. The rest of this article will also focus on the issue of copyright clearance in libraries. 


\section{Developing Information Literacy Education}

Because the MOOC course videos are usually short, the information contained in them is very limited, and the quality control of the course is not as strict as a traditional class. The two most important skills students need to have in order to succeed in MOOC learning are the ability to find existing information, and to filter secondary and additional information (Kop \& Hill, 2008). These two aspects of skills are related to information literacy. Research ability and he standard information literacy skill education is not understood by the teachers. It is not their focus but it is a concerned of librarians. The rich data generated by the platform can be used to analyze the social and economic backgrounds, learning strategies and performance of students so as to test their information needs and accomplishments, and apply the results to the next learning stage or the new learning cycle. This is consistent with the current emphasis on library functions in data collection and evaluation, and is also a new role given to libraries as "big data" warehouses and analysts (Luo, 2014).

\section{The Library Participates in the Core Task of MOOC Production: Copyright Cleaning}

There are many ways for libraries to participate in MOOC, but the main premise of this article is to deal with the copyright risk of MOOC. Again, it deals with the first precondition of the MOOC video copyright, which is to clean up the resources involved. Therefore, this article will focus on the library's copyright clean-up work. The purpose of the library is to master all the copyright-related information involved with the MOOC such as the copyright protection period, the type of works, the contact information of the right holder or legal person, the ownership of copyright, cooperation and entrustment (Qin, 2005). Since the copyright resources in MOOC are divided into two parts, MOOC course content and MOOC curriculum itself, it is necessary to start the copyright clearance in the library.

\section{COPYRIGHT CLEARANCE OF MOOC COURSE CONTENT}

\section{Preliminary Copyright Description of the Creator}

The library needs to investigate the copyright status of third-party reference materials used by MOOC producers. In order to reduce the workload and improve the work efficiency, the producer may request a copy of the copyright evaluation report and provide a preliminary description of the copyright status of the MOOC course content. A copyright description from the producer may be carried out in accordance with the following steps:

The first step is to distinguish between third-party information and the content Created by one's self. It is simple and feasible to distinguish the two parts of the content, and the creator can simply explain the process. Of course, the library also has a formal censorship responsibility to reduce the copyright risk of plagiarism.

The second step is to further differentiate reference materials from third party materials into public and proprietary materials. The legal significance of the distinction lies in the fact that thirdparty information belonging to the public domain may be arbitrarily used without permission and that the work under the protection of copyright law requires further consideration of whether it is reasonable use and how to obtain authorization. Generally speaking, the original meaning of the public domain in copyright law refers to "the state of the expiration of the right protection period" (Ginsburg, 2006). However, more scholars believe that the scope of public domain is far greater, at least including the following: (1) knowledge products that existed before the implementation of copyright law; (2) works that the copyright holder intends to put into the public domain; (3) works not protected by the lack of copyright protection elements; (4) works and ingredients that should be shared by mankind; (5) public domain based on fair use (Huang, 2008). MOOC producers can make a distinction between third-party reference materials. 
Third, for different types of work, the quantity and the use mode should be used as standards to make a preliminary judgement on whether "fair use" is applicable. As previously stated in this article, the openness and profit-making characteristics of MOOC limits the application of reasonable use, so one should be cautious whether MOOC constitutes reasonable use. In this context, the copyright guide of the Columbia University Library has been well used. This guide clearly indicates that fair use of online open courses is limited and should be used as a last resort. It also considers that reasonable use can only be considered as an option in two cases: when a teacher criticizes directly; and when the content is used in a new way. That is, when the purpose of using content in the course is completely different from the original purpose of the content creator. Further, the copyright guide details the definition of what circumstances can constitute a reasonable use and under what circumstances to suspect infringement for different types of works (Copyright Guidelines for MOOCs and other Public Online Courses, 2015). Duke University Library offers similar copyright guides (Fowler, 2013). The form of copyright guides to provide copyright services and advice for the non-professionals is lacking in domestic libraries at present, but should be made available in the future. Although the United States copyright law and Chinese copyright law have differences in their specific provisions, the basic principles are consistent. So MOOC producers can comply with the foreign University Library Copyright guides and make moderate adjustment based on the current "copyright law" in China.

Finally, for use of third-party information that does not constitute a reasonable use, the producer should specify the copyright status the information. This step contains the following aspects: whether the materials used belong to the works protected by copyright law; the kind of work, how long protection period is and limitation of rights; the holder of copyright is a natural person or a legal person and how long the protection period is; what rights the obligee enjoys and whether the act of using the works falls into the range of the users rights; whether there are other intellectual property right protections and whether the use of the work is subject to other restrictions based on those protections; whether or not it is necessary to apply to the unit or individual for permission; whether the original obligee has a copyright notice; whether permission has been obtained and whether the original license scope needs to be updated; and other copyright-related status (Zhang \& Li, 2016). What is not very clear about a work's copyright status should be highlighted in an assessment report.

\section{Verification of the Copyright Status of the Library}

After the producer submits the initial copyright statement, the library relies on its own professional advantages to verify the relevant criteria. This includes whether the distinction between public and proprietary areas are accurate, the fair use of the establishment, whether the copyright status is true and reliable and so on. It is possible to make no adjustments to the content which has been identified in the public domain, subject to reasonable use or license. However, for reasonable use the producer should be reminded to make a copyright declaration. The content of the statement should include the copyright owner, the source of the work and the scope of use. This is the requirement of fair use.

In the case of unauthorized and unclear copyright, one should work out the status to the copyright. Coursera restricts teacher's use of third party copyright works as the teaching foundation content. Courses require teachers to obtain the copyright authorization from the third party (Ye \& Ding, 2014). For unauthorized content, the library may use the following licensing modes depending on the amount and concentration of information required: individual licensing mode: the university library may obtain authorization directly from the copyright holder only when the individual documents require copyright authorization; collective management authorization mode: this is when the copyright of the required documents is concentrated in a publishing unit or copyright management unit, and the library may negotiate copyright with the agency and obtain a large number of copyright authorizations; and "department store" licensing mode: this model is mainly aimed at the use of the same copyright works in a variety products, or to use the same work with different rights through one, or a few, collective management organizations. Organizations can purchase a work of copyright to obtain the 
work in all other forms (such as animation, film, sound). "Department store" licensing mode avoids the copyright disputes caused by re-creation (Peng, 2015).

If the authorization is unsuccessful, the library should do its best to assist in the search for other authorized or free alternative resources such as resources in the public domain, shared resources, etc. According to the Duke University Library, there will be about $23.5 \%$ unanswered license applications even if the author has the contact information of the owner during application for copyright permission (Smith, 2013). If alternative resources are not feasible, the library may recommend that the MOOC curriculum teachers use "soft links" to guide students to copyrighted works without the need to embed copyrighted works in the course to reduce legal risks ( $Y e \& Y i, 2014)$. When the link mode is not available, Coursera, one of the three MOOC platforms, suggests that the best decision is to remove the unnecessary and copyrighted third-party content directly from the course.

\section{Copyright Clearance of MOOC Course Video}

In addition to containing third-party materials, MOOC also generates its own intellectual creation. The two parts of intellectual creation involved in the overall course as well as how to determine the right of ownership is a problem that cannot be ignored. Because MOOC videos rely on external dissemination once they are completed, they involve schools, producers, platforms and other beneficiaries in dealing with the third-party copyright relations. The internal copyright relationship also needs to be straightened out and this can be regarded as a complete copyright clearance.

First, there is the production of intellectual creations, and this part of the content is done independently by the author. The copyright does not necessarily belong to the individual creator. It may involve cooperative relations, entrusted relations, job relations, and so on. This creation should require the producers to make a copyright statement, explaining the specific rights or the part of the attribution cooperation that all authors have indicated and agreed to use, whether they expressly agreed to the right to belong and whether the work belongs to a job created for the completion of a task.

Another issue related to this is the overall rights attribution of the course video. In the traditional classroom teaching, the teacher's status is undoubtedly the most crucial. Therefore, in traditional classroom teaching, the teacher can determine rights attribution of the work in the course of the instruction. Copyright is enjoyed by the author, but the legal person or other organization has the right to use the work preferentially within its business scope. The author shall not permit a third person to use the work in the same manner as the unit without the consent of the unit within two years of completion of the work. However, in the MOOC environment, the rules of general duty works are not necessarily applicable. This is related to the divergence of the MOOC course video in the classification of works. MOOC videos rely on multimedia technology to produce, and there is no unified opinion on which type of work they should belong to. From the basic manifestation, MOOC videos are similar to film which contains images and sounds but it is not as difficult and sophisticated as film works. Therefore, the MOOC course video can be used as a film-making method under the premise of satisfying the copyright requirement. The copyright law of China makes special arrangement for the right attribution of film works: copyright is enjoyed by the investment side of the work namely the producer, writers, directors, photography, lyrics, and composer. Other authors only enjoy the right to signature and the right to receive compensation. In the MOOC environment, the cost of school investment in curriculum design, video production and other aspects has increased significantly. In dealing with MOOC and other service work's copyright issues, it is clear that is difficult to have a complete return on the initial investment of the school. If the right is directly attributed to the school, it may damage the creative enthusiasm of teachers. Therefore, the most reasonable and appropriate way is for teachers and schools to work together to determine the ownership of rights and the distribution of interests. In the case of copyright clearance, the library may require the producer to issue a written statement of the right attribution. 


\section{THE UNIVERSITY LIBRARY CAN REDUCE COPYRIGHT RISK THROUGH COOPERATION WITH MOOC PLATFORM}

It has been practically proven that it is time-consuming, and has a high cost in terms of economics and manpower to clean up the MOOC copyright in library. According Coursera statistics, the average course takes 380 hours to deal with copyright issues (Wang, 2014), and even after diligent clearance it may still be difficult to complete since colleges and universities are required to choose the right platform before the MOOC course is released. University libraries can reduce copyright risk through cooperation with the MOOC platform.

\section{How MOOC Platform Filtration Technology Can Further Complete Copyright Clearance}

As a result of the technical connection between the MOOC producer and the user, MOOC platforms can completely realize active shielding and even the removal of the technical effect of infringing works by developing network content identification and filtering technology. Therefore, it is feasible to filter the additional technology of the MOOC platform. Currently, the most feasible content filtering scheme is based on an intellectual content analysis filtering method, representing the development of content recognition and filtering technology (Sun \& Zhou, 2011). It uses the techniques of language analysis, image processing and machine learning to analyze the text, image or audio-visual works in depth. It automatically identifies the characteristics of the content that needs to be filtered and establish the index. It also analyzes whether the target file contains the above copyright content characteristics, thus facilitating a decision on whether to intervene or not (Cui, 2017).

Furthermore, MOOCs serve as a network user to provide content storage and publishing services. To actively publish the MOOC course it is required that content technology filtering is used in a reasonable manner. Generally speaking, if the probability of infringement and the probability of infringement loss is greater than the cost of preventive measures, it is reasonable for relevant subjects to take infringement prevention measures (U.S. v. Carroll Towing, 1947). The MOOC platform itself is not responsible for the MOOC curriculum, which is usually uploaded to the platform by the creator and then publicly disseminated through the platform. The copyright infringement risk of a MOOC course provided by the producer is substantial. Whether the technical filtration of the MOOC platform between the creator's uploading and the public communication is reasonable depends on whether the cost of prevention is economical and whether the effect is significant. The MOOC platform takes technical filtration precautions and its economic costs are mostly limited to the platform which has purely technical costs, and the effect is after the producers upload MOOC courses. This is the first time the courses are being made on the platform. Using technical filtering before releasing, can clearly distinguish whether the uploaded content is infringing or not. The alleged infringement of the curriculum must be communicated to the library in a timely manner in order to limit or even completely prevent the public dissemination of infringing content. Therefore, the MOOC platform is obligated to filter the technology in line with economic efficiency requirements.

\section{To Control the Impact of Infringement by the Requirements of the Safe Haven Rules on the Platform}

Even after the library's manual error-correcting and MOOC platform technology filtration, there may be copyright infringement. The MOOC platform, as a network service provider for a vast number of users, will often use the principle of safe haven to relieve its responsibility and then transfer the tort responsibility of the uploaded course to the person who uploads them. Although the MOOC platform is suspected of transferring responsibility, it is an effective way to control the infringement loss for the right's holder. According to the requirements of the Safe Haven Rule, the network service provider does not bear the tort liability when it receives an infringement notice. It promptly takes necessary measures of deletion, shielding, and disconnection and effectively controls the infringement 
behavior. Therefore, the MOOC platform should pay attention to copyright notices when releasing courses. The copyright notice contains two parts: first the MOOC producer or the MOOC platform releases the copyright information regarding the original work statement, the concrete content, third party material, right's holders, the source, the authorization scope, and so on. The MOOC producer reminds students to pay attention to the copyright issue statement (stating the MOOC course's use of other original materials, MOOC course video, the overall rights of ownership, responsibility, etc.) to inform users without permission to avoid unauthorized use. Educational institutions are obliged to inform students that materials related to the course may be protected by copyright (Crews, 2007).

The application conditions of the Safe Haven Rule also confirm the necessity of technology filtration on the MOOC platform. The third paragraph of Article 36 of the Tort Liability Act stipulates that where a network service provider "knows" that a network user is infringing upon the civil rights or interests of another person through its network services and fails to take necessary measures, it shall be jointly liable along with the network user, for any additional harm. The stipulation of "Know" may refer to two kinds of subjective states, which are "already know" and "should have known." At present, civil law scholars have not yet agreed on this issue. Some scholars believe that we should use the authoritative interpretation of the Civil Law Codification Office of the NPC Standing Committee, the idea of "knowing" includes both "clearly know" and "should know." Another scholar considers that the term "know" only represents a case of "already known" $(M a, 2017)$. "Know" includes the concept of "clearly knows" and is certain, but some of the violations are so obvious that a little attention would identify infringement. If "should know" is excluded then the network service provider has condoned harboring suspicion. Therefore, the concept of "know" should contain both "clearly know" and "should know." This understanding is consistent with the provisions of Article 22 of the Protection of the Right to Communication of Information Networks. While network service providers supply information storage space for service objects without liability, the third condition stipulates a subjective state of "do not know and there is no reasonable reason to know" any infringement of the works, performances, audio and video products. The concept of "should know" specifies who should be judged. It is generally believed that the "red flag standard," developed in American judicial practice, is worthy of reference. That is, the network service provider refers to the general cognitive criteria of a rational person's to determine the infringement acts such as the red flag. Otherwise the network service provider cannot claim the application of safe haven rules.

\section{THE LEGISLATIVE PROSPECT OF SOLVING THE MOOC COPYRIGHT PROBLEM}

\section{No Master Works Should Be Distinguished from Orphan Works}

The concept of orphan works was first proposed by the United States. According to the report on orphan works released by the United States Copyright Office in 2006, the term "orphan works" is used to describe a situation where the user wants to use a copyrighted work in a manner that is licensed by the copyright owner, but is unable to determine the identity of the copyright holder or to find the copyright holder (United States Copyright Office, 2006). Europe is equally concerned with the issue of orphan works. According to a Directive of the European Parliament and the Council of the European Union on the use of specific questions concerning the licensing of orphan works promulgated in 2012, the term "orphan works" refers to the inability to determine the rights of the person or the legal provisions of a copyright holder, and a diligent search cannot find the work of the right person (Directive 2012/28/EU). From the definitions, the works identified, located or found are basically used. "Orphan works" should be works which the user cannot ascertain the identity of the copyright owner even though the person is determined. These works do not contain any copyright which is inherited. In the so-called "can't determine the rights holder," unlike anonymous works, the author may exercise his right of signature by means of the real name, pseudonym and anonymity 
of the agency. Regardless of the manner in which the right of signature is exercised, the author, the rights holder or the original holder, the work is not "the author's unidentified work," as long as the contributor has provided the publisher with contact information for the publication of the work. "The author's unidentified work" means that the work is not signed and that it is impossible to verify the authorship in a normal way (such as a photograph or manuscript posted to a publishing house or newspaper or other department without attribution or contact information) (Guan, 2013).

"No master work" emphasizes that the identity of the copyright owner is not only determined but can also be found. The copyright owner and legal successors are dead and no other people has been bequeathed, although protection of property rights has not yet expired. Therefore, "no master works" shall only refer to "if the natural person who is the copyright owner dies and has no heir or bequest or a legal person or other organization terminated without a right or obligation to bear the protection period of the person and the term of protection has not expired." They are not orphan works. The key difference between no master work and the orphan works is if there is a real right person. If the existence of the real right person is unable to be determined and found, it is an orphan work. If a person lacks the right, it is a no master work. Under the legislative model of the two points of personal and property in China, copyright of "no master works" only refers to the property right of the works.

\section{The Legislative Prospect of No Master Works}

The copyright law of each country basically stipulates that the property rights of works can be transferred by means of inheritance. However, the treatment of "no master works" is divided into two different legislative models. The first mode of legislation is that the property right that no one inherits and has no bequest is destroyed and enters into public domain. As stipulated in Paragraph 1 of Article 62 of the Copyright Act of Japan, copyright will eliminate in the following cases: (1) when the copyright owner dies, the copyright shall be vested in the National Treasury in accordance with the provisions of article No. 959 of the Civil Code; and (2) After the dissolution of the legal person as a copyright owner in accordance with article No. 239, Paragraph 3 of the General Corporate Legal Person and the General Consortium Legal Person's Law and other corresponding copyright law, copyright should be returned to the treasury (Copyright Law Translation Group of 12 Countries, 2011). Japanese scholars explains this as "no heir, according to the cultural mission of copyright, and instead of returning to the library, it is better to use it as the public property of human society so that it can be freely used by ordinary people" (Chen, 2008).

The second model of legislation is that the property rights of the unclaimed and uninhabited works belong to the state. As stipulated in Paragraph 2 of Article 29 of the Russian Federation copyright and neighboring Rights Act, "where the author has no successor, the specialized agencies of the Russian Federation shall have full authority to protect the aforementioned rights." The Copyright Act of Viet Nam stipulates that where the copyright owner dies and cannot set an heir, the copyright is nationalized.

China's legislation generally complies with the second model, but it is slightly different. Article 19 of the Copyright Law stipulates that copyright belongs to the natural person, and the transfer of copyright is in accordance with the provisions of the law of succession. If the copyright belongs to a legal person, the copyright shall be enjoyed by the state after the loss of the legal person with rights and obligation following. In accordance with the provisions of the law on inheritance, property rights of copyright belong to the state. Inheritance which no one inherits or is bequeathed belongs to the state, the inheritance belongs to the state. If the deceased was a member of the collective ownership, the work will be owned by the collective ownership of the organization. Therefore, in China, there are two different forms: works which belong to the state and those which belong to the collective ownership.

The theory of civil law can be divided into two categories: hermeneutics and legislation. The interpretation of civil law is formed by the interpretation of the existing civil law norms. The legislative theory of civil law is about how to design a reasonable civil law standard and how to improve the existing civil law norms, views and theories. The purpose is to guide or influence the practice of civil legislation (Han, 2005). It should be noted that the interpretation of "no master works" is in line 
with the realistic structure of civil law, and it is helpful to solve disputes. However, in the legislative theory, "no master works" belongs to the state or the collective, whether it conforms to the ideal state of civil law norms or needs further discussion.

Due to the immaterial nature of the copyright object, it is impossible to apply the first account. However, compared with the ownership scheme of tangible property, the goal of "promoting the use of objects and settling social order" can be achieved by attributing "no master works" directly to the public domain, except for the state. The absence of ownership of the works has evolved into a problem that is good for the state and bad for the public. Whether it is from the system's objective of copyright law or the legal consequence, it is preferable to make "no master works" part of the public domain.

First of all, from the legislative purposes of copyright law, copyright law provides protection for the privacy of the author (copyright holder). The law's main purpose is to encourage creation and the protection of the author's private interests, which has always given way to the goal of social and cultural development. When the copyright owner and his heirs are no longer present, it is unreasonable to continue to provide legal protection for the works. Second, if the owner of a buried or concealed object is unknown, the law regulating ownership belongs to the state to solve the problem of scrambling, to promote using, and to prevent the tragedy of the commons caused by unknown ownership, which may damage the value the object should have. However, the tragedy does not acknowledge the premise of intangible copyright domain. The reason for the tragedy of the commons is that the physical objects are the personal belongings in a strict sense and the problems of their use are competitive and dissipative. The fundamental difference between works and objects is that works are in essence a kind of public product, which have the characteristics of sharing and consuming non-competitive information. Intellectual property has completely changed the fundamental structure of the object in the theory of "The Tragedy of Commons," and treated it as "Commons property." Not only will works not encounter the embarrassment of the tragedy of the Commons but on the contrary, the knowledge and information placed in the public domain can promote interaction with, and openness about the characteristics of the work, so that they can achieve a dynamic prosperity and enrichment (Zhang \& Huang, 2009).

\section{The Legislative Prospect of Orphan Works}

There are two different legislative models for the use of orphan works. In Canada, Article 77 of the Copyright Act stipulates that the user shall submit an application for the use of the work to a specialized agency and provide evidence that tried to find the right holder with no results. "Orphan works" can be used after the application has been approved and the use fee has been paid. In the second model from the United States, the user can use the "orphan works" without paying the use fee when trying to find the right person without result. After the rights holder has appeared, they may sue the user. If the court determines that the user has fulfilled his or her obligation in seeking the rights holder, he or she may enjoy the limitation of liability, so that the user is required to pay a reasonable amount of compensation to the right holder and is not compensable in the case of non-commercial use. In cases where reasonable compensation has been paid, the court cannot issue an injunction with respect to the act of using "orphan works" as a deductive work. However, if the users do not do their best to find the copyright owner, they have to bear the consequences of paying punitive damages (Han, 2009).

There is no provision for the use of orphan works in the current copyright law of China. However, in the revised draft of the copyright law, the first, second draft and the third drafts all stipulate that the user may apply to the Copyright Administration Department of the State Council for the use of the copyrighted work. Therefore, China is adopting the Canadian type of deposit-keeping mode. Because the amendment draft of copyright law does not involve practical operation, the specific matter is appointed to the Copyright Administration Department of the State Council separately. Future stipulations should make more detailed provisions on the premise of using orphan's works trying to find the right person without effect. 


\section{CONCLUSION}

With the rapid development of MOOC, copyright risks related to the MOOC cannot be ignored. MOOC rely on multimedia technology, and the fragmented characteristics of its sources involve more complicated legal relationships. The profitability of the MOOC platform itself makes MOOC videos more prone to copyright infringement compared to traditional works. The core way for libraries to participate in MOOC is using their own professional expertise to make a comprehensive and systematic copyright clearance of MOOC course contents and MOOC course videos. Moreover, with platform filtering techniques and port rules, libraries can work with the MOOC platform to implement further technical filtering of MOOC. Furthermore, the rapid development of MOOC provides the realistic basis for speeding up the legislative process for the adjustment of copyright regulations. Therefore, it is necessary to perfect the copyright legislation related to MOOC.

\section{ACKNOWLEDGMENT}

This article is the 2016 National Social Science Fund Key Project "The network time Open Education resources introduction and the utilization intellectual property problem research"(16ATQ002); 2015, the key project of Tianjin philosophy and social Science planning "research on library coping strategies under the background of MOOC"(TJTQ15-001); The Ministry of Education 2016-2017 Foreign textbooks Center research project "Internet + " The study of intellectual property rights in MOOC education" The letter of the High Secretary [2016]56. 


\section{REFERENCES}

Calter, M. (2013). MOOCs and the library: Engaging with evolving pedagogy. Retrieved from http://library. ifla.org/160/1/098-calter-en.pdf

Campbell v. Acuff-Rose Music, Inc. (1994).

Chen, Z. (2015). Copyright Cleanup: New Function of Library Copyright Management Based On MOOC. Library Journal, (7), 18-20.

Copyright Guidelines for MOOCs and other Public Online Courses. (2015). Retrieved from https://copyright. columbia.edu/content/dam/copyright/copyright $\% 20$ guidelines $\% 20$ open $\% 20$ online $\% 20$ courses $\% 20$ moocs $\% 20$ (00201903-4x9672E).pdf

Copyright Law Translation Group of 12 Countries. (2011). Copyright law of 12 countries. Beijing: Qinghua University Press.

Crews, K. D. (2007). New Copyright Law for Distance Education: The Meaning and Importance of the TEACH Act. Intellectual Property, 17(1), 91-96.

Cui, G. (2016). Treat the Game Copyright Seriously. Intellectual Property, (2), 3-18.

Cui, G. (2017). Network Service provider Copyright Content Filter Duty. Chinese Jurisprudence, (2), 215-237.

Fang, J. (2014). The Development of MOOC and Its Challenge to Traditional Education. Journal of Huabei University of Science and Technology, (5), 90-94.

Fang, Z. (2016). Comparison and Legal Regulation of MOOC and Traditional Classroom Teaching in the Perspective of Copyright. Publishing Wide Angle, (10), 79-81.

Feng, X. (2009). Study on the Legitimacy of the Copyright Fair Use System. Modern Jurisprudence, 31(4), 29-41.

Fowler, L. (2013). Drawing the Blueprint As We Build: Setting Up a Library-based Copyright and Permissions Service for MOOCs. Retrieved from http://www.dlib.org/dlib/july13/fowler/07fowler.html

Ginsburg, J. C. (2006). Une Chose Publique? In The Author's Domain and the Public Domain in Early British, French and Us Copyright Law (pp. 636-670). Cambridge.

Guan, Y. (2013). Reflection and Comparison of the Solutions to the Problems of Orphan Works in Europe and America-At the Same Time, to Evaluate the Amendment of the Relevant Articles in China's Copyright Law. Hebei Law, 31(6), 135-142.

Han, S. (2005). Interpretation and Legislation of Civil Law. People's Court Newspaper.

Han. Y. (Trans.). (2009). The 2008 Orphan Works Act of the United States. Global Law Review, 31(1), 151-160.

Intellectual Property Protection in China. (2013). Australian University Seeks Copyright Law Reform to Enable MOOC. Retrieved from http://www.ipr.gov.cn/guojiiprarticle/guojiipr/201301/17224

Kop, R., \& Hill, A. (2008). Connectivism: Learning theory of the future or vestige of the past? International Review of Research in Open and Distance Learning, 9(3), 1-13. doi:10.19173/irrodl.v9i3.523

Huang, H. (2008). Research on Public Domain in Copyright Law. Modern Jurisprudence, (3), 46-55.

Librarians. (2013). Your most valuable MOOC supporters. Retrieved from https://oedb.org/library/features/ librariansyour-most-valuable-mooc-supporters/

Li, C. (2008). The Treatment of the Property Right of the Heirless Works. Electronic Intellectual Property, (1), 10-11.

Li, Q., \& Liu, N. (2016). The Design and Making Method of Teaching Video in MOOC-An Empirical Study Based on Coursera and EDX Platform Course. Modern educational. Technology, (7), 64-70.

Luo, B. (2014). Summary Research of MOOC and the Role of University Library. Library and information. Work (Reading, Mass.), 58(3), 130-136. 
Ma, Y. (2017). Tort Liability of Internet Service Provider for Searching Link Behavior. Law Review, (3), 55-63.

Peng, J. (2015). University Library Analyzes on the Issue of MOOC Copyright Cleaning. Library Construction, 250(4), 30-33.

Reil, L. R. (2012). Inaugural Address. Retrieved from http://president.mit.edu/speeches-writing/inauguraladdress

Smith, K. (2013). Copyright issues and legislation, licensing, scholarly publishing the problem with permission. Retrieved from https://blogs.library.duke.edu/scholcomm/2013/07/18/the-problem-with-permission/JHJsthash. O301HRC8.dpuf

Qin, H. (2014). Rise of MOOCs and the Role of Library. Journal of Chinese Library, 40(2), 19-26.

Qin, K. (2005). Characteristics of Multimedia Works and the Relevance to the Protection of Intellectual Property Rights. Journal of Henan Library, 19(4), 60-61.

Qin, K. (2005). Introduction to the Copyright Protection of Digital Library. Meteorological Publishing House.

Sun, Y., \& Zhou, X. (2011). Research Progress of Content Filtration Technology. Information Security and Communication Confidentiality, 9(9), 45-46.

United States Copyright Office. (2006). Report on Orphan Works. Retrieved from https://www.copyright.gov/ orphan/orphan-report.pdf

Vuopala, A. (2010). Assessment of the Orphan works issue and Costs for Rights Clearance. Retrieved from https://ec.europa.eu/information_society/activities/digital_libraries/doc/reports_orphan/anna_report.pdf

Wang, L. (2014). Analysis of Copyright Characteristics of MOOC. Technology and Publishing, (7), 86-89.

Wang. Q. (2013). Foreign Copyright Case Translation. Beijing: Law Publishing House Press.

Wu, H. (1996). Analysis of Legal Value of Fair use System. Legal Science, (3), 30-38.

Ye, L., \& Yi, X. (2014). Research on the Copyright of MOOCs in the View of Library. Journal of University Library, 32(5), 25-33.

Ye, W., \& Ding, Y. (2014). Research on Copyright System in the Development of MOOC. Technology and Publishing, 33(2), 13-17.

Zhang, D., \& Zheng, X. (2016). Study on the Copyright Risk of MOOC Education Model. Journal of Gui Zhou Normal University (social. Science edition, (1), 154-160.

Zhang, L., \& Li, Y. (2016). Copyright Assistance Advisor: The New Role of Library under the Environment of MOOC. Information Theory and Practice, 39(6), 20-26.

Zhang, Y., \& Huang, H. (2009). The Rationality of Public Domain in Copyright Law. Journal of Southwest University of Nationalities, 30(8), 145-152.

Zou, L., \& Chen, J. (2015). Study on the Fair use of MOOC Education. Intellectual, (1), 21-25.

Libin Zhang is a researcher in Nankai University Library. Mr. Zhang has received nearly 10 funds including the National Social Science Fund, fund supported by Foreign Teaching Materials Center of China Education Ministry and so on. Mr. Zhang has published 120 papers, some of which are published in National core periodicals. His research areas mainly focuses on service providers of digital resources, open educational resources, introduction of the problem of MOOC services and library information literacy education.

Guo Wang is a PhD in Civil and Commercial Law, and is now a lecturer of Law School of Tianjin Commercial University. She has published 10 papers. Her interest areas mainly focus on intellectual property law.

Yihang $\mathrm{Li}$ is a PhD in Civil and Commercial Law, and is now a Postdoctoral fellow at Shenzhen Graduate School of Harbin Institute of Technology. She has published 10 papers. Her interest areas include intellectual property law and standardization. 
Qun Hao has a master degree of Library Science, and is now a librarian in Fudan University and a Master tutor. She has published 30 papers. Her interest areas include information management, information service and so on.

Huiming Chai has a master of Library Science, and is now a librarian in Tianjin Conservatory of Music. He has published 15 papers. His interest areas include information management, information service and so on.

Jiamin Wu is now a student of the law school of Nankai University. She has published 3 papers in the area of intellectual property law. 